\title{
Analyzing the Effects of Sectoral Public Spending On Human Development in Nigeria: Evidence from Panel Data
}

\author{
Richardson Kojo Edeme \\ Department of Economics, University of Nigeria, Nsukka
}

\begin{abstract}
This paper analyzed the effects sectoral public spending on human development in Nigeria using data from 20 states for the period1999-2012. Data on each state were generated from various issues of the Accountant-Generals' Reports, Central Bank of Nigeria Annual Report and Statement of Accounts and United Nations Development Programme Reports. For robustness of the analysis, total, recurrent and capital public spending on education, health, agriculture, rural development, energy, housing, environmental protection and portable water resources are employed as predictors of human development. The result depicted that there is a positive functional relationship between education, health, agriculture, rural development, energy, housing, environmental protection and portable water resources expenditure and human development; an indication that expenditure on these sectors fosters human development. Beside, the efficacy of education, health, agriculture, rural development and portable water in improving human development is greater than that of energy, housing and environmental protection. A further analysis of recurrent and capital expenditures reveals that recurrent and capital expenditure has both positive and negative effects on human development across states and period under consideration. However, the relative effect of capital expenditure in improving human development was greater than that of recurrent expenditure.
\end{abstract}

Keywords: Public spending, Human development, Panel data, least square method

\section{Introduction}

One of the basic challenges facing most developing countries is how to accentuate human development. It in recognition of the importance that international community decided on a target year of 2015, when all countries should achieve specific targets in health, poverty and inequality reduction, education, water and sustainable environment, housing as well as food security. Towards the attainment of these goals governments in both developed and developing countries have been carrying out expenditure on different sectors. In Nigeria, government at the federal and state levels have been playing prominent roles in improving human development to such an extent that one should expect a positive correlation between progress in expenditure in these sectors and human development expenditure. This optimism may, however, be suspected because despite growth in public spending on different sectors, the pace of human development has been slow and so far its growth has been rather unstable and erratic. For instance, human development index (HDI) grew positively by 0.3 percent in 1987 but declined to 0.1 percent in 1988. In 1992 and 1996 it grew negatively by 0.2 percent and -2.7 percent respectively. For these years, government expenditure grew by 4.7, 8.4 and 5.8 percent respectively. Although, there was an increase in per capita income, but this increase did not manifest in improvement in the quality of life of the citizens as there is high incidence of poverty, unemployment and low literacy rate and life expectancy (CBN 2010). This is more pronounced across zones in Nigeria where human profile shows that a great disparity exist in human development and compares with data on inequality measure, gender empowerment measure, gender empowerment measure, gender development measure, human poverty index and human development index as shown in Table 1 below.

Table 1: Human Development Summary Statistics in Nigeria, by Zones

\begin{tabular}{|c|c|c|c|c|c|}
\hline Zones & $\begin{array}{c}\text { Human } \\
\text { Development Index } \\
\text { Value }\end{array}$ & $\begin{array}{c}\text { Human Poverty } \\
\text { Index }\end{array}$ & $\begin{array}{c}\text { Gender } \\
\text { Development } \\
\text { Measure }\end{array}$ & $\begin{array}{c}\text { Gender Empowerment } \\
\text { Measure }\end{array}$ & $\begin{array}{c}\text { Inequality } \\
\text { Measure }\end{array}$ \\
\hline South South & 0.573 & 26.61 & 0.575 & 0.251 & 0.41 \\
\hline South East & 0.471 & 26.07 & 0.455 & 0.315 & 0.38 \\
\hline South West & 0.523 & 21.50 & 0.507 & 0.285 & 0.48 \\
\hline North East & 0.332 & 48.90 & 0.250 & 0.118 & 0.42 \\
\hline North West & 0.420 & 44.15 & 0.376 & 0.244 & 0.44 \\
\hline North Central & 0.490 & 34.65 & 0.478 & 0.49 \\
\hline
\end{tabular}

Source: Nigeria Human Development Report (NHDR) 2008-2009 
Human development which is broadly viewed as a process of expanding people's choice and opportunities open to people is to improve living standard as well as the welfare of the citizens. These choices can be infinite and changes over time and space. However, the three most important critical and socially valuable from among these choices are the choice to lead a long and healthy life, the choice to acquire knowledge and be educated and have access to resources needed for a decent level of living as a nation develops (UNDP 2001).In essence, human development should improve the availability and widen the distribution of basic life sustaining needs such as decent living, longer life, personal protection; improved living standard and environmental sustainability which ultimately improve well-being through the provision of more jobs, better education and other humanistic values (Goulet 1991, UNSRID 1992 Todaro and Smith 2011). It could be argued from the above therefore that per capita income is a necessary but not a sufficient measure of human development, but enhanced quality life as manifested in higher educational attainment, easier access to employment and healthier life, food security and access to portable water, affordable housing, sustainable environment and greater life expectancy. In attaining all these, public spending has a great role to play (Sen 1985; 2000, Seers 1989, Anand and Ravallion 2003). Although empirical findings have shown that there is a contemporaneous transformation of social, economic and environmental sectors that impacts on human development, studies differ on which services sectors and components are most influential in human development. Beside Easterly and Levine (1997) opine that human development efforts in a country should reflect a country's specific conditions especially if such a country possesses large federating units and are heterogeneous and where the various efforts to improve the well-being of the citizens or accentuate poverty may differ according to expenditure ability and priority, environmental, ethnic and political influences. Therefore, if human development efforts of a country are to be encompassing and useful for the purpose of internal policies aimed at achieving sustainable development, the impact of public spending on human development at the subnational levels should be assessed. And even though aggregate analysis is a useful tool, it offers little help in policy initiatives. Yet there have not been such study at the state level in Nigeria. Moreover, the traditional approaches to the measurement of human development have been outcome of attentions employed in defining the development process. Traditionally, development was conceived as the capacity of a national economy whose initial economic condition has been more or less static for a long time, to generate and sustain increases in its national product (Todaro and Smith 2011). Adopting this approach, it was discovered that a significant number of developing countries did not attain enviable improvement in human development. As for those that recorded significant increase, it was also observed that the well-being of majority of the citizens remained for the most part, remain unchanged, and in some cases actually worsened (CBN 2000; World Bank 2000, Hagha 2001, Alayande 2003, Orubu 2003). In view of this, there has been resurgence of interest in the relationship between public spending and human development for there can be little doubt about the value of higher real income in opening up possibilities of living decent lives and improved well-being that are not available at lower levels of income.

In light of the above, this paper presents a spatial analysis of the effects of sectoral public spending and how much they have translated into improving human development in Nigeria. This study contributes to the pool of literature in several ways. First we use a new data set that significantly extends the coverage of sectors, spending components and states. This is because we employed total, recurrent and capital expenditure on education, health, agriculture, rural development, energy, housing, environmental protection and portable water resources as predictors of human development. Beside, previous specific, cross-sectional and panel studies used different countries and they have been limited in depth or in breadth. By taking into consideration many sectors and expenditure components in our analysis, we offer additional depth and robustness to the analysis.

Second, this study used panel data. The use of panel avails us the opportunity of exploring both crosssectional and time-series variation in sectoral public spending and its impact on human development over the 13-year period. We therefore control for the effects of the variables in our regression with both the fixed effects and random effects model. Beside, our estimates are based on pool (panel) least squares (PLS) regression model applied to and calibrated for 20 states in Nigeria. Thirdly, we adopt a new measure of human development, the human development index (HDI) because of its reflection of the inadequacy of other measures. A study at the state level is crucial not only because it is necessary to substantiate the contributions or efforts of the state governments in human development but also because such a study is apt to provide policy guides relating to prioritization and review of the pattern and distribution of public spending in human development in Nigeria. The outcome of this study therefore, will help design strategies and draw inferences that could form policies, strategies and interventions for improving human development throughout the country.

\section{Theoretical Framework}

Human development finds its theoretical underpinnings in Sen (1985) capabilities theory. This theory considers a person's capability to have varying functioning vectors and to enjoy the corresponding well-being inherent in the growth process. This perspective have shifted the analysis of development to the vector of not 
only attributes (as in the more traditional utilitarian) or even the original basic needs view of human welfare, for instance, income, education, health, to the vector of possible opportunities available to individuals in a particular country. Naturally, there is a link between the two and these opportunities are affected by certain attributes of the individual. For example, a starving or uneducated person would have fewer choices to economic opportunities and benefits than a healthy and educated person. Yet the capability approach goes far beyond assessing individual efforts to acquire these benefits. Rather, it considers the efforts of government in enhancing or influencing individual's ability to acquire more opportunities which the development process provides. Infact, Anand and Kanbur (1993) found that the most effective means of human development flows through government budgetary expenditure, central or local. However, the strengths of this effect depend on the nature of expenditure, sector and component. In this regard, the government must identify priority sectors that have the highest potential for human development improvement. For instance, as education and health improve and become more broadly based, low income people are better able to seek out economic opportunities. Therefore, public spending on human development should be distributed predominantly to low income groups and areas since it is here that the highest marginal impact will be had (Ranis and Stewart 2003). The development literature has highlighted the importance of human well-being in the development process. In essence, the benefits of a sustained growth process are expected to trickle down to the people in form of longer life, more jobs and other numerous economic and non-economic opportunities. Therefore, access of the people to basic amenities such as portable water, health care facilities, quality education, affordable and decent housing and sustainable environment are fundamental to an enhanced quality of life which is a manifestation of human development. At policy level, in view of the low level of human development and because of the critical role of human development in the growth process of an economy, much responsibility is often placed on the government to spend on some sectors to promote human development. The major sectors or areas which spending is often necessity are education, health, agriculture, rural development, energy, housing, environmental protection, portable water resources, transport and communication (UNDP 2006). Public spending represents a form of government intervention designed to stimulate the economy through correction of market failure so as to redistribute resources equitably, promote economic growth and improve human welfare. The essence of public expenditure therefore stems from the fact that the functioning of the market, by itself activate the signaling, response and mobility of economic agents to achieve efficiency in both static (allocative efficiency) and dynamic (shift in production frontiers) terms ( Musgrave and Musgrave 1984, Arndt 1998). For any Paretoefficient allocation, there exist a set of prices that support that allocation as market equilibrium, but each with a different distribution of welfare. The issue is to decide which Pareto-efficient allocation conforms to societal notion of distributive justice. Apparently, the market cannot do it because the social welfare function is obviously not a market construct. Therefore, it must evolve from government intervention efforts (Rao 1998, Bathia 2004). The theorem of welfare economics is further supported by the government-led growth or so-called demand-led growth theory. The government-led growth theory argues that government spending is used, both as a stimulant for capital investments and a source of needed social welfare in the society. Hence, the theory supports government spending in public goods where such expenditure further supports investment in public goods, which in turn enhances productivity growth along with the supply side improvement. The theory, however, argues that demand for goods and services must be sustained at high levels, and this requires public expenditure (Robert 2001). It is also important to note that there have been government failures due to intervention. Infact, Neo-classicists such as Bos (1986) Veron (1987), Swansan and Worlde - Semait 1989, Van de Walle (1989) opine that government involvement in socio-economic activities constitutes a barrier to the economic development process. On the contrary, there is evidence that government intervention has been growth-enhancing in many Sub-Saharan Africa countries. Much of the economic growth of the past generation in these countries have depended on and benefited from high levels of public spending on some services, including high technology and education. It should be noted that public expenditure is equally needed to provide an enabling environment for the private sector to strive. Much of the impact of public expenditure on the economy can be viewed as a means of providing infrastructure for economic growth; in the broadest sensesocial infrastructure like education and health and physical environment like roads, energy, water resources, environmental protection and rural development. For the market to operate smoothly to create growth and improve well-being these services and infrastructure are required and yet in most cases, it is beyond the capacity of the private sector to provide. Hence, it is usually the government who provides for these so as to guarantee well-being in the society. This is the crucial link between public expenditure and human development. Theoretically, public expenditure should promote human development for a variety of reasons. First, human development is an end itself; a means to achieving freedom for all and opening people's capabilities and makes life more abundant. It is also a means of improving productivity, reducing reproduction and lowering the desired family size. Besides, it reduces poverty and contributes to a healthy civil society, political participation and reduces civil disturbances. Indeed, it is good for the social, economic and physical environment development of the economy (Streeten, 1994). Of the various effects of expenditure in these areas however, those relating to 
capital expenditure appear to be most paramount. However, growth in recurrent expenditure has effect on human development since they are capable of reducing access to improved human development (Emini and Fofack 2004).

\subsection{Existing Literature}

The nature of impact of public spending on human development is a recurring study in literature. The traditional analysis in Nigeria focuses on capital spending while both capital and recurrent expenditure is carried out on different sectors of the economy to engender human development. But in recent years, following the rise in recurrent spending at the detriment of capital spending components, theoretical research has turned to the analysis of recurrent-capital effects on human development especially when such spending is carried out by the federal, state and local government. Chakraborthy (2003) explore the relationship between capital health and education spending and human development in panel data involving 14 developed and developing countries. Not surprising this author find that capital spending has a positive impact on human development. Shantayanan, Vinaya and Zon (2004) used data from 15 developing countries for 6 years to show that an increase in the share of current expenditure has positive and statistically significant growth effect on human development. Conversely, the relationship between the capital component of expenditure and human development is negative. Thus, seemingly productive expenditure could become unproductive. Diamond (1990) based on the study of 38 developing countries found that capital expenditure on education have positive impact on human development and exerted its influence on poverty reduction. Bigsten and Levin (2000) posit that the compositions of government expenditure are critical determinants in human development. They are also of the view that if government is undertaking fiscal reforms, three types of impact should be considered. First, when relative prices and factor income change, income distribution and poverty will change. Second, the composition of government expenditures affects sectoral productivity and hence human development. Third, change in public expenditure on services such as education and health have an impact on household's well-being. In line with this and based on simulations with econometric model of the Swedish thirteen different public expenditure, Dahlberg and Jakobsson (1997) shows that the effects of an increase in capital education, agriculture and rural development spending on human development are found to differ considerably depending on which sector expenditure is expanded. In similar vein, Dorosh (1996) found that change in relative prices and factor incomes following reduced government current expenditures hurt mainly urban households, due to the bias of government employment. While protecting urban households from a short-term income loss, this incidentally has a longterm negative impact on human development. Diamond (1990) study focused on public education capital expenditure in developed countries for 1989-1991. The study was based on a 1990/1991 survey of 38 countries and employed planned budget data reported directly by the countries. A cross-sectional approach was used to explain the effect of public expenditure on human development. A study of the Indonesian economy and applying SAM, four classes of government recurrent expenditure on respectively education and health wages and salaries on other goods and services, and household transfer; and nine classes of government capital expenditure on agriculture, industry and mining, energy, transport and tourism, education, health, housing and water works, general services and other activities have been identified (Keunig and Thorbecke 1999). Schultz (1980) asserts that capital spending on education has a significant effect on human development. Reinikka and Collier (2001) used data from a series of household surveys in Uganda from 1992-1999 and found that education, rural development and agriculture have a major positive impact on human productivity and improving rural poverty, which are connected to human development. In the same vein, Fan, Zhang and Rao (2003), adopting different methods and different country data for 1992, 1995 and 1999, analyzed the effect of capital public spending on agriculture and rural development on human development in Uganda. They found that expenditure on agriculture and rural development impacts positively on human development. Dao (1995), using cross-section of countries estimated the effect of disaggregated government expenditure on human development and conclude capital spending is hampered where which make government spending less efficient. Also Feyzioglu, Swaroop and Zhu (2000) presented result based on disaggregated government expenditure variables using panel data and asserts that when resources are transferred for recurrent purposes, there may be a slowdown in the improvement of human development in the society, from distributional perspective. Another strand in the literature examines the relationship between public spending and human development. At the International Food Policy Research Institute some studies have been conducted along this theme for different countries. These studies are Fan, Hazelland and Thorat (2000) on India; Hao and Fan (2001) on Vietnam; Fan, Zhang and Zhang (2002) on China and Jitsachon; Methakunavut (2003) on Thailand; Jaff (2003) on Cameroon; Wildlife (2006) for Cuba. Studies have assessed the impact of public expenditure on economic and environmental sectors variables on human development. For instance, using rural areas in Indian, Fan, Zhang and Zhang (2000) found government expenditure on rural infrastructure and health to have a visible impact on human development. For their study in China in 2002, they found expenditure on education to have the largest impact on human development and poverty reduction. A major profound agreement of these studies is that 
public expenditure has influenced human development of these countries. These studies along with some others harp on the need for the government to play greater role in fostering human development through public expenditure However, the extent of influence differs from country to country. In Nigeria, studies on the effect of capital and recurrent expenditure and human development have been conducted with varying outcomes. For instance Okojie (1995) asserts that capital spending education and health raises per capita GNP and reduces poverty. Specifically, public expenditure on health results in tremendous savings due to less illness, longer life expectancy and increased vitality. Similarly, Grammy and Assane (1996) showed that capital spending on education promotes growth in per capita income. The outcome of the studies reveals that education substantially increases the potentials of women and their productivity. Ekpo (1996) using data for the period 1960-1992 found that expenditure on certain components of the economy is low while expenditure on well-being enhancing variables is minimal. Aggregating capital and recurrent expenditure, the study conclude that the model of development, which emphasize balanced growth, redistribution with growth and the provision of basic needs be adopted in government spending. In a review of the trends of public expenditure pattern in Nigeria, the International Monetary Fund (IMF) (2006) identify directions and instrument of restructuring government expenditure patterns at both macro and sectoral levels and assesses the impact of government reform efforts since 2001. The outcome of the study is that states' capital budgets are often unrealistic. In addition, states face an acute shortage of technical and human capacity to design and implement reforms. While empirical evidence here is spottier, theory however suggests that a decentralized locally accountable government system may have advantage in resource allocation and service delivery.

\section{Data And Methodology}

The study use variables from 20 states systematically selected from the 6 geo-political zones in Nigeria. The states are: Bayelsa, Delta, Edo and Cross River (South-South Zone) Osun, Ondo, Ogun and Ekiti (SouthWest Zone) Kano, Jigawa and Kaduna (North-West Zone); Taraba, Gombe and Bauchi (North-East Zone); kwara, Plateau and Benue (North-Central Zone); Abia, Ebonyi and Enugu (South-East Zone). The data used in this study are secondary data obtained from the selected states and various other official sources. The data extends from 1999 to 2012. Actual total, recurrent and capital expenditure on education, health, agriculture, rural development, energy, housing, environmental protection and water resources are employed. The choice of these sectors is borne out of the fact that they represent services which are essential in promoting healthier living, high literacy rate, food security and decent housing, combat inequality, reduce poverty, create jobs and improve human welfare. Beside, empirical literature primarily supports the choice of these sectors because they are key expenditures that can be used to transfer the benefits of economic development to the economically deprived individuals in the society and improve human capabilities (Anand and Ravallion 1993, Jorgenson 1998, Romer and Romer, 1999, Jha 2000, Chakraborty 2003, Rana 2003, Liman 2004, UNDP 2004, NISER 2005, Anderson, de Ranzio and Levy 2006, Montanaso 2006, World Bank 2007). Human development is proxied by human development index (HDI). The choice of HDI is borne out of the fact that it represents the average condition of living of all people in a country, zone or state irrespective of sex. It comprises a wider definition of well-being beyond gross domestic product (GDP) per capita or per capita income and other measures of human development and gives a less skewed picture of distribution than that presented by GNP per capita. Data for the study were generated from various Accountant Generals' Report of the selected States, Various Years. Central Bank of Nigeria Annual Report and Statement of Accounts and United Nations Development Programme (UNDP) Human Development Reports (Nigeria), Various Years.

\subsection{Model Specification}

The model for this study follows Chakraborty (2003) with an extension to reflect the nature of data used in our analysis. The functional relationship between government expenditure, recurrent and capital expenditure can be stated separately as:

$$
\begin{aligned}
& H D X=f(E D, H T, A G, R D, E N, H S, E P, W R) \\
& H D X=f(R E, R H, R A, R R, R N, R H, R P, R W) \\
& H D X=f(C E, C H, C A, C R, C N, C H, C P, C W)
\end{aligned}
$$

In panel form, the above relationships can be re-estimated linearly as:

$$
\begin{aligned}
& H D X_{i t}=\alpha_{1}+\alpha_{2} E D_{2 i t}+\alpha_{3} H T_{3 i t}+\alpha_{4} A G_{4 i t}+\alpha_{5} R D_{5 i t}+\alpha_{6} E N_{6 i t}+\alpha_{7} H S_{7 i t}+\alpha_{8} E P_{8 i t}+\alpha_{9} W R_{9 i t}+U_{i t} \\
& \begin{array}{c}
(4) \\
H D X_{i t}=\beta_{1}+\beta_{2} R E_{2 i t}+\beta_{3} R H_{3 i t}+\beta_{4} R A_{4 i t}+\beta_{5} R R_{5 i t}+\beta_{6} R N_{6 i t}+\beta_{7} R S_{7 i t}+\beta_{8} R P_{8 i t}+\beta_{9} R W_{9 i t}+U_{i t} \\
\ldots \ldots \ldots \ldots \ldots \ldots \ldots \ldots \ldots \ldots \ldots \ldots \ldots \ldots \ldots \\
H D X_{i t}=\varphi_{1}+\varphi_{2} C E_{2 i t}+\varphi_{3} C H_{3 i t}+\varphi_{4} C A_{4 i t}+\varphi_{5} C R_{5 i t}+\varphi_{6} C N_{6 i t}+\varphi_{7} C S_{7 i t}+\varphi_{8} C P_{8 i t}+\varphi_{9} C W_{9 i t}+U_{i t}
\end{array}
\end{aligned}
$$

$A$ - priori, $\alpha$ 's and $\varphi$ 's are parameters $>0$; while $\beta$ 's $\geq 0$ 
Taking into consideration the time and space dimension of our data, the pooled OLS models are estimated using the principal alternatives: Fixed effects model (FEM) and Random effects model (REM). In FEM, the individuality of each state or each cross-sectional unit is taken into consideration. Thus, we allow the intercept vary for each state and still assume that the slope coefficients are constant across states. For the fixed effect therefore, we employ dummies to re-estimate equations (4), (5) and (6) to obtain their corresponding LSDV model as:

$H D X_{i t}=\lambda_{1}+\lambda_{2} D_{2 i}+\lambda_{3} D_{3 i}+---+\lambda_{19} D_{19}+\alpha_{2} E D_{2 i t}+\alpha_{3} H T_{3 i t}+\alpha_{4} A G_{4 i t}+\alpha_{5} R D_{5 i t}+\alpha_{6} E N_{6 i t}+\alpha_{7} H S_{7 i t}+\alpha_{8} E P_{8 i t}$

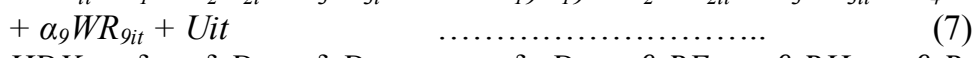

$H D X_{i t}=\delta_{1}+\delta_{2} D_{2 t}+\delta_{3} D_{3 i}+----+\delta_{19} D_{19}+\beta_{2} R E_{2 i t}+\beta_{3} R H_{3 i t}+\beta_{4} R A_{4 i t}+\beta_{5} R R_{5 i t}+\beta_{6} R N_{6 i t}+\beta_{7} R H_{7 i t}+\beta_{8} R P_{8 i t}+$

$\beta_{9} R W_{9 i t}+U_{i t}$
$H D X_{i t}=7_{1}+7_{2} D_{2 i}+7_{3} D_{3 i t}+\ldots \ldots \ldots \ldots \ldots \ldots \ldots \ldots \ldots \ldots \ldots \ldots \ldots \ldots \ldots \ldots \ldots \ldots \ldots \ldots \ldots \ldots$
$\eta_{19} D_{19}+\varphi_{2} C E_{2 i t}+\varphi_{3} C H_{3 i t}+\varphi_{4} C A_{4 i t}+\varphi_{5} C R_{5 i t}+\varphi_{6} C N_{6 i t}+\varphi_{7} C H_{7 i t}+\varphi_{8} C P_{8 i t}+$ $\varphi_{9} C W_{g_{i t}}+U_{i t}$

By implication, $\lambda_{1}$ is the intercept of each state while $\alpha_{2}, \alpha_{3}, \alpha_{4}---\alpha_{19}$, the differential intercept coefficients. On the contrary, the random effects model can be estimated by assuming the intercept of the model to be a random variable. Therefore, rather than treating $\alpha_{l i}, \beta_{l i}$ and $\varphi_{l i}$ as fixed in equation (4), (5) and (6); they are assumed to have a mean value of $\alpha_{1}, \beta_{1}$ and $\varphi_{1}$ respectively. The intercept value for each state can therefore be written as:

$\alpha_{i i}=\alpha_{1}+e_{1}$

$\beta_{i i}=\beta_{1}+e_{1}$

$\varphi_{i i}=\varphi_{1}+e_{l}$

where $e i$ is the random error term with a mean value of zero and variance of $\delta^{2} e$. Substituting equations (10), (11) and (12) into equations (4), (5) and (6) respectively gives:

$H D X_{i t}=\alpha_{1}+\alpha_{2} E D_{2 i t}+\alpha_{3} H T_{3 i t}+\alpha_{4} A G_{4 i t}+\alpha_{5} R D_{5 i t}+\alpha_{6} E N_{6 i t}+\alpha_{7} H S_{7 i t}+\alpha_{8} E P_{8 i t}+\alpha_{9} W R_{9 i t}+f_{i t}$

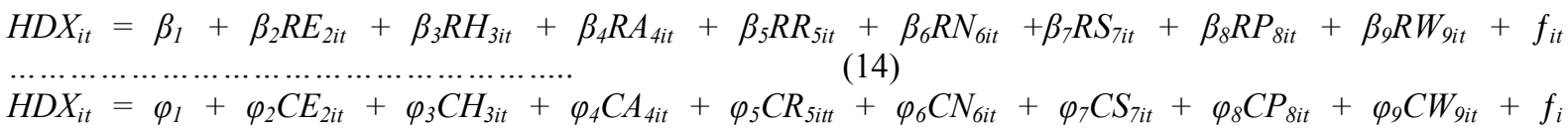
$H D X_{i t}=\varphi_{1}+\varphi_{2} C E_{2 i t}+\varphi_{3} C H_{3 i t}+\varphi_{4} C A_{4 i t}+\varphi_{5} C$
$(15)$

with $f_{\mathrm{it}}=e_{i}+U_{i t} ; e_{i}$ as the cross-section or individual-specific error component and $\quad U_{i t}$ combined time series and cross-section error component

where $\quad i=1,2,3,--20$ (ith cross-sectional unit)

$t=1,2,3,--13$ (ith period)

$i$ denotes cross-sections and $t$ denotes the time-periods.

If the null hypothesis of no fixed-effects is rejected by the data, we can estimate the null hypothesis of fixed effects. To further test for the appropriateness of the fixed-or random-effects model, we performed the Hausman Specification Test. If the models are however, specified correctly and if $\varepsilon_{i}$ is uncorrelated with the explanatory variables, then the two estimates should not differ significantly. In this study, however, we produce estimates of the two methods as well as the specification test. In classical regression analysis, $\mathrm{R}^{2}$ is employed as a popular measure of goodness of fit. Since fixed-effects model can be estimated by OLS using dummy variables, we can evaluate the goodness of fit by reporting its $\mathrm{R}^{2}$. However, similar measure cannot be derived for the random effects model. Rather, we report another measure calculated as the correlation squared of the predicted dependent variable. If it is calculated from the predictions of the dependent variable in equations (4) - (6), it is referred to as $\mathrm{R}^{2}$ (Overall). If it is calculated from the predictions of the deviations of the dependent variable as in equations (7) - (9), it is known as $\mathrm{R}^{2}$ (within). For the fixed effects model, $\mathrm{R}^{2}$ (within) is also referred to as ordinary $\mathrm{R}^{2}$. The empirical results of this study have been obtained with the use of $\boldsymbol{E}$-Views (10.0 versions) computer packages of econometric data analysis and estimation.

\section{Empirical Results And Interpretation}

Although, in some estimates, there are no systematic difference between the two models in terms of goodness of fit, the $\mathrm{R}^{2}$ overall is consistently higher for the fixed effects model in comparism with the OLS models. Based on the model specification tests it is evident that the assumption of no individual effects, whether fixed or random, is not supported in the data. In addition, it is clear that ignoring the panel nature of the data, as in OLS will result in appropriate estimates. For comparative purpose, the results of the fixed effects and OLS models were presented. 
Table 1: The impact of public spending on Human Development

\begin{tabular}{|c|c|c|c|c|c|c|c|c|}
\hline & \multicolumn{2}{|c|}{ State } & \multicolumn{3}{|c|}{ Year } & \multicolumn{3}{|c|}{ Variable } \\
\hline & Fixed & OLS & & Fixed & OLS & & Fixed & OLS \\
\hline Constant & & & & & & & $\begin{array}{l}0.238 \\
(1.68)\end{array}$ & $\begin{array}{l}0.225 \\
(0.14)\end{array}$ \\
\hline Kaduna & -0.015 & -0.022 & 1999 & & & ED & $\begin{array}{l}0.034 \\
(2.54)^{* *}\end{array}$ & $\begin{array}{l}0.030 \\
(1.04)^{*}\end{array}$ \\
\hline Kebbi & 0.026 & 0.019 & 2000 & & & HT & $\begin{array}{l}0.025 \\
(1.48)^{*}\end{array}$ & $\begin{array}{l}0.009 \\
(0.61)^{*}\end{array}$ \\
\hline Jigawa & 0.213 & 0.201 & 2001 & & & $\mathrm{AG}$ & $\begin{array}{l}0.021 \\
(1.10)\end{array}$ & $\begin{array}{l}0.005 \\
(0.06)\end{array}$ \\
\hline Adamawa & 0.216 & 0.215 & 2002 & & & RD & $\begin{array}{l}0.018 \\
(1.02)^{*}\end{array}$ & $\begin{array}{l}0.000 \\
(0.19)\end{array}$ \\
\hline Bauchi & 0.187 & 0.049 & 2003 & & & EN & $\begin{array}{l}0.010 \\
(0.24)\end{array}$ & $\begin{array}{l}0.002 \\
(0.19)\end{array}$ \\
\hline Borno & 0.141 & 0.140 & 2004 & & & $\mathrm{HS}$ & $\begin{array}{l}0.003 \\
(0.02)\end{array}$ & $\begin{array}{l}0.002 \\
(0.01)\end{array}$ \\
\hline Niger & 0.236 & 0.284 & 2005 & & & EP & $\begin{array}{l}0.009 \\
(1.02)^{*}\end{array}$ & $\begin{array}{l}0.007 \\
(0.68)^{*}\end{array}$ \\
\hline Kogi & 0.207 & 0.203 & 2006 & & & WR & $\begin{array}{l}0.0013 \\
(1.02)^{*}\end{array}$ & $\begin{array}{l}0.001 \\
(0.48) \\
\end{array}$ \\
\hline Plateau & 0.109 & 0.100 & 2007 & & & & & \\
\hline Anambra & 0.156 & 0.147 & 2008 & & & & & \\
\hline Imo & 0.205 & 0.208 & 2009 & & & & & \\
\hline Enugu & 0.426 & 0.424 & 2010 & & & & & \\
\hline Delta & 0.195 & 0.188 & 2011 & & & & & \\
\hline Akwa-Ibom & 0.296 & 0.289 & 2012 & & & & & \\
\hline Cross River & 0.466 & 1.440 & & & & & & \\
\hline Edo & 0.458 & 0.404 & & & & & & \\
\hline Oyo & 0.329 & 0.311 & & & & & & \\
\hline Lagos & 0.287 & 0.217 & & & & & & \\
\hline Ondo & 0.205 & 0.200 & & & & & & \\
\hline Ekiti & 0.198 & 0.192 & & & & & & \\
\hline $\mathrm{R}^{2}$ (Ordinary) & 0.79 & & & & & & & \\
\hline $\mathrm{R}^{2}$ (Overall) & 0.72 & 0.66 & & & & & & \\
\hline
\end{tabular}

Note: The figure in parenthesis denotes t-statistic; *Significant at 1 percent level**Significant at 5 percent level Source: Authors' Calculations.

The result in Table 1 indicates that variation in human development across states and period can be explained by sectoral public spending. The coefficient of the each of the explanatory variables shows that public spending on education, health, agriculture, rural development, energy, housing, environmental protection and portable water resources have positive functional relationship with human development. In relative terms, an increase of $\mathrm{N} 1$ million per education spending will increase human development by 0.034 percentage point. Similarly, a unit (that is N1 million) increase in health expenditure can lead to a significant improvement in human development equally 0.025 percentage point. The coefficient of agriculture expenditure portrays that if expenditure increases by $\mathrm{N} 1$ million, human development increases by 0.021 percentage point; an increase in rural development expenditure by N1 million increases human development by 0.018 percentage point. Also, an increase in energy, housing, environmental protection and water resources increases human development by $0.10,0.003,0.009$ and 0.001 percentage points respectively. In terms of magnitude, education has the highest impact. A proportionate increase in expenditure in other sectors may help improve human development, though to a much smaller magnitude as compared to education that has the loudest impact, although the coefficient is not statistically significant. In all, the positive relationship between education, health, agriculture, rural development, energy, housing, environmental protection and water resources expenditure and human development is suggestive that public expenditure encourages human development, although public expenditure has not contributed significantly to human development over time. This is evidence in the low coefficients of the explanatory variables. The low coefficients may be due to multicollinearity problem. Therefore, to overcome this, we estimated a panel least square with white hetroskadascity-standard errors in which we regressed between human development and combined education, health, agriculture, rural development, energy, housing, environmental protection and water resources expenditure. 
Table 2: The impact of combined Education, Health, Agriculture and Rural Development, Energy, Housing, Environmental Protection and Water Resources spending on Human Development

\begin{tabular}{|l|l|l|l|l|l|l|l|l|}
\hline & \multicolumn{2}{|c}{ State } & \multicolumn{3}{c|}{ Year } & \multicolumn{3}{c|}{ Variable } \\
\hline & Fixed & OLS & & Fixed & OLS & & Fixed & OLS \\
\hline Constant & & & & & & Combined ED, & $\begin{array}{l}0.246 \\
(9.72)^{* *}\end{array}$ & $\begin{array}{l}0.177 \\
(2.06)^{*}\end{array}$ \\
\hline Kaduna & -0.058 & -0.085 & 1996 & 0.039 & 0.033 & HT, AG, RD, & & \\
\hline Kebbi & -0.030 & -0.042 & 1997 & -0.245 & -0.256 & EN, HS, EP & $\begin{array}{l}0.175 \\
(1.95)^{*}\end{array}$ & $\begin{array}{l}0.067 \\
(0.48)\end{array}$ \\
\hline Jigawa & -0.039 & -0.036 & 1998 & -0.063 & -0.092 & And WR & & \\
\hline Adamawa & -0.017 & -0.029 & 1999 & -0.018 & -0.088 & expenditure & & \\
\hline Bauchi & -0.146 & -0.156 & 2000 & 0.002 & 0.002 & & & \\
\hline Borno & -0.262 & -0.261 & 2001 & 0.092 & 0.088 & & & \\
\hline Niger & -0.246 & -0.258 & 2002 & 0.178 & 0.172 & & & \\
\hline Kogi & 0.027 & 0.012 & 2003 & -0.045 & -0.056 & & & \\
\hline Plateau & -0.066 & -0.092 & 2004 & 0.014 & 0.019 & & & \\
\hline Anambra & -0.269 & -0.300 & 2005 & -0.111 & -0.087 & & & \\
\hline Imo & 0.068 & 0.055 & 2006 & -0.103 & -0.114 & & & \\
\hline Enugu & -0.195 & -0.222 & 2007 & -0.009 & -0.008 & & & \\
\hline Delta & 0.207 & 0.200 & 2008 & 0.090 & 0.082 & & & \\
\hline Akwa-Ibom & 0.262 & 0.256 & & & & & & \\
\hline Cross River & 0.205 & 0.204 & & & & & & \\
\hline Edo & 0.193 & 0.193 & & & & & & \\
\hline Oyo & -0.096 & -0.111 & & & & & & \\
\hline Lagos & 0.041 & 0.026 & & & & & & \\
\hline Ondo & 0.062 & 0.055 & & & & & & \\
\hline Ekiti & 0.101 & 0.099 & & & & & & \\
\hline $\mathrm{R}^{2}$ (Ordinary) & 0.72 & & & & & & & \\
\hline $\mathrm{R}^{2}$ (Overall) & 0.65 & 0.62 & & & & & & \\
\hline
\end{tabular}

Note: The figure in parenthesis denotes t- statistic; *Significant at 1 percent level;

**Significant at 5 percent level

Source: Authors' calculations

The result in Table 2 further shows that there exist a positive relationship between public expenditure and human development but did not differ significantly when we employed each of the expenditure variables (see table 4). The outcome confirms other studies such as World Bank (1993), Jose (2005), Keuning and Thorbecke (1999), Fan, et al (2003). However, the cross-section and period specification reveals that public spending has negative effect on human development in some states and period under consideration. This could be attributable to low spending on some sectors like education and rural development in relation to other sectors that do not have direct positive effect on human development. On the recurrent spending, two estimates was conducted using an instrumental variables regression in which we instrumented education, health, agriculture, energy, housing, environmental protection and water resources since it has been discovered earlier that expenditure on rural development is most states was capital in nature. In the first analysis, recurrent expenditure has both positive and negative effects on human development. Recurrent spending on education, energy, environmental protection and water resources have positive effect on human development while recurrent health, agriculture and housing expenditure have negative effect on human development. Interestingly, we also find recurrent spending to have negative effect on human development in some states while it has positive effect in other states. This is also true for some period under consideration (see Table 3). In the second estimate where the sample is restricted to states involved in recurrent expenditure on rural development, the result confirms that education, rural development, and housing recurrent spending have negative effect on human development while health, agriculture, energy, environmental protection and water resources recurrent expenditure has positive growth effect on human development. In essence, recurrent spending on rural development has positive effect on human development in Kaduna, Kebbi, Jigawa, Bauchi, Kogi, Anambra, Imo, Enugu, Delta, CrossRiver, Lagos, Ondo and Ekiti states while its effect is negative in Niger and Plateau states (Table 4).

Table 3: The Effect of recurrent spending on Human Development (with recurrent expenditure on rural development dropped).

\begin{tabular}{|l|l|l|l|l|l|l|l|l|}
\hline & \multicolumn{2}{|c|}{ State } & \multicolumn{3}{c|}{ Year } & \multicolumn{3}{c|}{ Variable } \\
\hline & Fixed & OLS & & Fixed & OLS & & Fixed & OLS \\
\hline Constant & & & & & & & & \\
\hline Kaduna & -0.119 & -0.126 & 1999 & 0.144 & 0.141 & RED & $\begin{array}{l}0.002 \\
(0.98)^{*}\end{array}$ & $\begin{array}{l}0.006 \\
(0.33)\end{array}$ \\
\hline Kebbi & -0.161 & -0.188 & 2000 & -0.057 & -0.072 & RHT & $\begin{array}{l}-0.008 \\
(-1.35)^{*}\end{array}$ & $\begin{array}{l}-0.002 \\
(-0.19)\end{array}$ \\
\hline Jigawa & -0.111 & -0.092 & 2001 & -0.232 & -0.113 & RAG & -0.004 & -0.024 \\
\hline
\end{tabular}




\begin{tabular}{|l|l|l|l|l|l|l|l|l|}
\hline & & & & & & & $(-0.49)$ & $(-0.37)$ \\
\hline Adamawa & -0.102 & -0.077 & 2002 & -0.017 & -0.007 & RRD & & \\
\hline Bauchi & -0.187 & -0.181 & 2003 & -0.101 & -0.091 & REN & $\begin{array}{l}0.004 \\
(1.36)^{*}\end{array}$ & $\begin{array}{l}0.001 \\
(0.49)\end{array}$ \\
\hline Borno & -0.141 & -0.092 & 2004 & 0.112 & 0.099 & RHS & $\begin{array}{l}-0.002 \\
(-0.02)\end{array}$ & $\begin{array}{l}-0.009 \\
(-0.01)\end{array}$ \\
\hline Niger & -0.106 & -0.128 & 2005 & 0.146 & 0.128 & REP & $\begin{array}{l}0.013 \\
(0.88)^{*}\end{array}$ & $\begin{array}{l}0.007 \\
(0.41)\end{array}$ \\
\hline Kogi & -0.109 & -0.007 & 2006 & 0.108 & 0.103 & RWR & $\begin{array}{l}0.012 \\
(1.34)\end{array}$ & $\begin{array}{l}0.010 \\
(0.89)\end{array}$ \\
\hline Plateau & -0.104 & -0.068 & 2007 & -0.030 & -0.087 & & & \\
\hline Anambra & -0.105 & -0.127 & 2008 & 0.138 & 0.136 & & & \\
\hline Imo & -0.190 & -0.195 & 2009 & 0.246 & 0.242 & & & \\
\hline Enugu & 0.191 & 0.204 & 2010 & -0.019 & -0.012 & & & \\
\hline Delta & 0.302 & 0.301 & 2011 & 0.047 & 0.041 & & & \\
\hline Akwa-Ibom & 0.266 & 0.267 & 2012 & & & & & \\
\hline Cross River & 0.209 & 0.211 & & & & & & \\
\hline Edo & 0.202 & 0.200 & & & & & & \\
\hline Oyo & 0.121 & 0.111 & & & & & & \\
\hline Lagos & 0.131 & 0.125 & & & & & & \\
\hline Ondo & 0.012 & 0.012 & & & & & & \\
\hline Ekiti & 0.008 & 0.008 & & & & & & \\
\hline $\mathrm{R}^{2}$ (Ordinary) & 0.79 & & & & & & & \\
\hline $\mathrm{R}^{2}$ (Overall) & 0.75 & 0.58 & & & & & & \\
\hline
\end{tabular}

Note: The figure in parenthesis denotes t- statistic; *Significant at 1 percent;**Significant at 5 percent Source: Authors' calculations

Table 4: The effect of recurrent spending on Human Development (cross-section with recurrent expenditure on Rural Development).

\begin{tabular}{|c|c|c|c|c|c|c|c|c|}
\hline & \multicolumn{2}{|c|}{ State } & \multicolumn{3}{|c|}{ Year } & \multicolumn{3}{|c|}{ Variable } \\
\hline & Fixed & OLS & & Fixed & OLS & & Fixed & OLS \\
\hline Constant & & & & & & & $\begin{array}{l}0.247 \\
(0.14)\end{array}$ & $\begin{array}{l}0.360 \\
(0.33)\end{array}$ \\
\hline Kaduna & 0.002 & -0.002 & 1999 & & & RED & $\begin{array}{l}-0.003 \\
(-0.14) \\
\end{array}$ & $\begin{array}{l}-0.016 \\
(0.05) \\
\end{array}$ \\
\hline Kebbi & 0.002 & 0.002 & 2000 & & & RHT & $\begin{array}{l}0.020 \\
(0.52)^{*}\end{array}$ & $\begin{array}{l}0.018 \\
(0.49)\end{array}$ \\
\hline Jigawa & 0.121 & 0.108 & 2001 & & & RAG & $\begin{array}{l}0.006 \\
(0.13) \\
\end{array}$ & $\begin{array}{l}0.002 \\
(0.01) \\
\end{array}$ \\
\hline Adamawa & & & 2002 & & & RRD & $\begin{array}{l}-0.232 \\
(-0.07) \\
\end{array}$ & $\begin{array}{l}-0.245 \\
(-0.14) \\
\end{array}$ \\
\hline Bauchi & 0.002 & 0.002 & 2003 & & & REN & $\begin{array}{l}0.005 \\
(1.13)^{*}\end{array}$ & $\begin{array}{l}0.002 \\
(0.97)^{*}\end{array}$ \\
\hline Borno & 0.188 & 0.176 & 2004 & & & RHS & $\begin{array}{l}-0.009 \\
(-0.14) \\
\end{array}$ & $\begin{array}{l}-0.002 \\
(0.33) \\
\end{array}$ \\
\hline Niger & -0.039 & -0.055 & 2005 & & & REP & $\begin{array}{l}0.021 \\
(0.12)\end{array}$ & $\begin{array}{l}0.000 \\
(0.83)\end{array}$ \\
\hline Kogi & 0.208 & 0.205 & 2006 & & & RWR & $\begin{array}{l}0.069 \\
(0.10)\end{array}$ & $\begin{array}{l}0.063 \\
(0.12)\end{array}$ \\
\hline Plateau & 0.012 & 0.246 & 2007 & & & & & \\
\hline Anambra & 0.002 & 0.002 & 2008 & & & & & \\
\hline Imo & 0.002 & 0.002 & 2009 & & & & & \\
\hline Enugu & 0.039 & 0.03 & 2010 & & & & & \\
\hline Delta & 0.557 & 0.692 & 2011 & & & & & \\
\hline Akwa-Ibom & & & 2012 & & & & & \\
\hline Cross River & 0.018 & 0.014 & & & & & & \\
\hline \multicolumn{9}{|l|}{ Edo } \\
\hline \multicolumn{9}{|l|}{ Oyo } \\
\hline Lagos & 0.561 & 0.448 & & & & & & \\
\hline Ondo & 0.063 & 0.03 & & & & & & \\
\hline Ekiti & 0.002 & 0.000 & & & & & & \\
\hline $\mathrm{R}^{2}$ (Ordinary) & 0.76 & & & & & & & \\
\hline $\mathrm{R}^{2}$ (Overall) & 0.63 & 0.50 & & & & & & \\
\hline
\end{tabular}

Note: The figure in parenthesis denotes t- statistic, ${ }^{*}$ Significant at 1 percent; ${ }^{* *}$ Significant at 5 percent Source: Authors' calculations

In the two analyses therefore, recurrent health, environmental protection and water resources expenditure has positive effect and housing recurrent spending negative effect on human development. Thus, only recurrent health, housing, environmental and water resources expenditure has consistent effect on human 
development in both analyses. Relative to recurrent spending on education, health, rural development, energy and housing, recurrent expenditure on health, environmental protection and water resources tends to improve human development. This may be attributable to the dominance of recurrent spending in some sectors and years covered by the study. This finding does not however contradict our theoretical expectations of an ambiguous relationship between recurrent expenditure and human development that increase in recurrent expenditure may or may not improve human development.

Table 5: The effect of public capital spending on Human development

\begin{tabular}{|c|c|c|c|c|c|c|c|c|}
\hline & \multicolumn{2}{|c|}{ State } & \multicolumn{3}{|c|}{ Year } & \multicolumn{3}{|c|}{ Variable } \\
\hline & Fixed & OLS & & Fixed & OLS & & Fixed & OLS \\
\hline Constant & & & & & & & & $\begin{array}{l}-0.269 \\
(-0.02)\end{array}$ \\
\hline Kaduna & -0.165 & -0.166 & 1999 & 0.178 & 0.175 & CED & $\begin{array}{l}0.004 \\
(1.71)\end{array}$ & $\begin{array}{l}0.001 \\
(0.08)\end{array}$ \\
\hline Kebbi & -0.023 & -0.052 & 2000 & -0.012 & -0.013 & $\mathrm{CHT}$ & $\begin{array}{l}0.012 \\
(2.04)\end{array}$ & $\begin{array}{l}0.09 \\
(0.38)\end{array}$ \\
\hline Jigawa & -0.021 & -0.013 & 2001 & -0.013 & -0.016 & CAG & $\begin{array}{l}0.006 \\
(1.52)\end{array}$ & $\begin{array}{l}0.006 \\
(0.57)\end{array}$ \\
\hline Adamawa & 0.115 & 0.111 & 2002 & -0.143 & 0.137 & CRD & $\begin{array}{l}0.016 \\
(1.10)\end{array}$ & $\begin{array}{l}0.013 \\
(0.00)\end{array}$ \\
\hline Bauchi & -0.079 & -0.074 & 2003 & -0.132 & 0.129 & CEN & $\begin{array}{l}-0.001 \\
(0.33)\end{array}$ & $\begin{array}{l}0.001 \\
(0.28)\end{array}$ \\
\hline Borno & 0.116 & 0.092 & 2004 & 0.018 & 0.111 & CHS & $\begin{array}{l}-0.001 \\
(-0.96)\end{array}$ & $\begin{array}{l}-0.001 \\
(-0.92)\end{array}$ \\
\hline Niger & 0.231 & 0.230 & 2005 & 0.121 & 0.092 & CEP & $\begin{array}{l}0.0008 \\
(1.33)\end{array}$ & $\begin{array}{l}0.005 \\
(0.98)\end{array}$ \\
\hline Kogi & 0.022 & 0.021 & 2006 & 0.133 & 0.140 & CWR & $\begin{array}{l}0.002 \\
(0.09)\end{array}$ & $\begin{array}{l}0.002 \\
(0.06)\end{array}$ \\
\hline Plateau & 0.180 & 0.178 & 2007 & -0.079 & -0.083 & & & \\
\hline Anambra & 0.236 & 0.242 & 2008 & -0.019 & -0.058 & & & \\
\hline Imo & -0.260 & 0.268 & 2009 & 0.020 & 0.029 & & & \\
\hline Enugu & -0.021 & -0.022 & 2010 & -0.100 & -0.026 & & & \\
\hline Delta & 0.225 & 0.225 & 2011 & 0.121 & 0.119 & & & \\
\hline Akwa-Ibom & -0.294 & -0.285 & 2012 & & & & & \\
\hline Cross River & -0.261 & -0.206 & & & & & & \\
\hline Edo & 0.539 & 0.483 & & & & & & \\
\hline Oyo & -0.034 & -0.000 & & & & & & \\
\hline Lagos & 0.344 & 0.303 & & & & & & \\
\hline Ondo & 0.120 & 0.090 & & & & & & \\
\hline Ekiti & -0.012 & 0.103 & & & & & & \\
\hline $\mathrm{R}^{2}$ (Ordinary) & 0.72 & & & & & & & \\
\hline $\mathrm{R}^{2}$ (Overall) & 0.89 & 0.68 & & & & & & \\
\hline
\end{tabular}

Note: The figure in parenthesis denotes t-statistic; *Significant at 1 percent

**Significant at 5 percent

Source: Authors calculation

The results in Table 5 above shows that capital expenditure on education, health, agriculture, rural development, environmental protection and water resources has positive relationship with human development while the relationship between capital expenditure on energy and housing and human development is negative. The positive correlation implies that as capital expenditure on education, health, agriculture, rural development, environmental protection and water resources increases, human development also increases. Conversely, as capital spending on energy and housing increases human development deceases. This implies that capital spending on energy and housing are unproductive and therefore has a decreasing effect on human development. The coefficient on the indicator of capital education (0.004), health (0.012), agriculture (0.06), rural development (0.016), environmental protection $(0.008)$ and water resources $(0.002)$ is an indication that per capital education, health, agriculture, rural development and environmental protection improves human development. In relative terms, an increase in per capital spending on education, health, agriculture, rural development, environmental protection and water resources will improve human development by $0.004,0.01$, $0.06,0.02$ and 0.01 points while energy and housing capital expenditure reduces human development by 0.01 (approximately), respectively, although the coefficients are statistically insignificant. The positive relationship between capital education, health, agriculture, rural development, environmental protection and water resources expenditure and human development is in conformity with our theoretical expectation and collaborate earlier studies such as Diamond (1990) and Chakraborthy (2003). Relative to capital expenditure on education health, agriculture, rural development, environmental protection and water resources, capital spending on energy tends to lower human development by 0.01 points approximately. Capital spending on housing has decreasing effect 
on human development as well. The result further suggests that capital expenditure on some sectors such as energy and housing are important for building infrastructure, but they may not necessarily improve human development directly since negative evidence was found according to our estimation. The cross-sectional analysis indicates that capital spending is positively correlated while it is negatively correlated with human development in some states and years under consideration. States with higher capital spending on education, health, rural development and agriculture have higher human development index. Overall, the cross-state results confirm the importance of capital expenditure in influencing human development. In terms of magnitude, it seems that a proportionate increase in capital spending relative to recurrent expenditure will lead to a significant improvement in human development. Thus, a larger share of recurrent expenditure reduces human development and a higher capital expenditure increases it. The result also provides evidence of the importance of education, health, agriculture, rural development and environmental protection in improving human development.

\section{Conclusion}

Using panel data of 20 states in Nigeria from 1999-2012, this study found that public spending on education has the highest effect on human development, followed by health, agriculture, rural development and energy, environmental protection, housing and water resources in descending order. Their specific coefficients, though positive, they are statistically insignificant; an indication that public expenditure has not impacted significantly on human development. The effect of recurrent expenditure on human development was best predicted using instrumental variables regression. The result reveals that recurrent expenditure on health, energy, environmental protection and portable water resources has positive effect on human development while recurrent rural development expenditure has negative effect. However, the cross-state and period estimation depicts that recurrent expenditure has both positive and negative effects on human development. The panel estimation of the relationship between capital spending and human development shows that capital spending has both positive and negative correlation with human development across states and time. Most notably, education, health, agriculture, rural development, environmental protection and water resources spending improves human development, though it is not robust. Relative to capital spending on education, health, agriculture, rural development and water resources expenditure, capital energy and housing spending tends to lower human development. The outcome suggests that such expenditure might help develop infrastructure, but they might not help improve capabilities that fosters human development. An important policy implication of our analysis is that if human development is to appreciate considerably across states in Nigeria, then it is portentous to stress that spending on education, health, agriculture, rural development, energy, housing, environmental protection and portable water resources must be further improved. The results, however do not suggest that spending on energy, housing and environmental protection should be curtailed. Rather, the results do suggest that any further increase in public expenditure on human development in the future should concentrate on education, health, agriculture, rural development and portable water resources. However, any increase in human development spending must emphasize the relative importance of capital spending compared to the current pattern of allocating higher proportion to the recurrent component. For improvement in human development across states in Nigeria, it is therefore imperative that a synergy of strategies and actions is required. In line with this, the following recommendations are made:

i). Firstly, human development expenditure by the states should be further improved and sustained. This is because our analyses have shown that public expenditure has a positive functional relationship with human development.

ii) Beside, such increases should focus more on education, health, agriculture, rural development and portable water resources since they have positive marginal impact on human development rather than focusing more on housing and energy. Despite increase in energy and housing, these sectors have not contributed significantly to human development.

iii) Moreover, there should be a switching in expenditure from recurrent to capital expenditure; yet it is the capital expenditure generates more productive resources that can improve human capabilities. Because of this, recurrent expenditure has had a decreasing effect on the performance of capital expenditure on human development. To increase the performance of capital expenditure o the provision of infrastructure needed to accelerate economic development, there is need to reduce drastically recurrent expenditure.

iv) It is further suggested that for human development to improve, capital expenditure should be further improved. One of the assured means of doing this is to reduce the bulk of recurrent expenditure on administration because such expenditure is corruptive in nature.

v) Consequently, there should be serious constitutional reforms in expenditure pattern in the country so that the distributional impact of public expenditure on human development would be felt.

vi) Finally, states in Nigeria should work together to develop an enabling environment and framework for equitable human development expenditure that would benefit all in the near future. This will go a long way in ensuring consistency in achieving consistency in human development expenditure among the states in Nigeria. 


\section{References}

[1]. Accountant Generals' Report (1999-2012), Various States:

a. Adrian, G and P.O Nadkami (2001), Protecting the Environment for Human Development, a four country study: Botswana, Ghana, Honduras and Senegal. ESMAP Technical Paper, March

b. Alayande, B. A (2003), Determinant of Vulnerability to Poverty in Nigeria: A Probit Analysis. Consultant Report for the World Bank /NPC Social Risk Assessment Exercise.

c. Alesine, A and D. Rodrick (1992), "Expenditure Distribution, Political Conflict and Human Development". In: Cukierman, A Hercowitz, Z and Leiderman (Eds). Political Economy, Growth and Business Cycle,Cambridge: MIT Press: 23-50

[2]. Anand, S and R1 Ravallion (1993), "Human Development in Poor Countries: On the Role of Private Income and Public Services". Journal of Economic Perspectives 7, (1) December: 135-150.

[3]. Anand, S. and R Kanbur (1991), "Public Policy and Basic Needs Provision. Iteration and Achievement in Developing Countries". In: Dreze and S (eds). The Political Economy of Hunger. Vol. 3 Oxford Claredun

[4]. Ardndt H. W (1998), Market Failure and Underdevelopment, World Development 16 (2)

[5]. Benerjee, A and A. Newman (1998), Human Welfare and the Process of Development. Journal of Political Economy 10(2): 274-298

[6]. Central Bank of Nigeria (1999-2012), Annual Report and Statement of Accounts, Abuja.

[7]. Central Bank of Nigeria (2010), "Nigeria's Development Prospect: Poverty Assessment and Alleviation study". Central Bank Nigeria Research Department.

[8]. Ceplan, P. (2004), Human Basic Needs: The Case of Sri Lanka”. World Development. Vol. 8 (3).

[9]. Chakraborty, Lekhas (2003), "Public Expenditure and Human Development: An Empirical Investigation". Paper Presented at International Conference on Inequality, Poverty and Human Well-Being, Helsinki, 30-31 May.

[10]. Desgupta, P. and M Weale (1992), On Measuring the Quality of Life. World Development 20 (1): 119-131

[11]. Demery, L. (2003), Analyzing the incidence of Public spending on Well-being”. In: Bourgugnon and L.A. Pereira da Silva (eds). The impact of Economic policies on Poverty and Income Distribution: Evaluation Techniques and Tools, New York: the World Bank and Oxford University Press: 41-68.

[12]. Douglas, B. and F. Willem (1996), "Rural Energy in Developing Countries: A Challenge for Human Development”. Annual Review Energy Environment, 21: $499-539$

[13]. Ekpo, A.H. (1996), Pattern of Public Expenditure in Nigeria 1960-1992. In: Economic Reform and Macroeconomic Management in Nigeria, Ariyo (Ed) Ibadan University Press

[14]. Emini C.A. Fofack, (2004), “A Financial Social Accounting Matrix for the Integrated Macroeconomic for Poverty Analysis: Application to Cameroon with a Fixed- Price Multiplier Analysis”. World Bank Policy Research Working Paper, 3210, February

[15]. Easterly, W and R. Levine (1994), Africa's growth strategy: Politics and ethnic Division. Quarterly Journal of Economics, 112 Fan, S. Hazelland, P. and S. Throat (2000), "Linkage between Government Spending, Human Development and Poverty in Rural India". IFPRI Research Report, 110, Washington, D.C.

[16]. Fan, S. Zhang, L., and X. Zhang (2002)," Growth, Inequality and Poverty in Rural China: The Role of Public Expenditure". IFPRI Research Report, 125, Washington D.C.

[17]. Feyzioglu, T., V. Swaroop and M.Zhu (2000), "Modeling the Determinant of Humna development expenditure in Sub- Saharan African Journal of African Economy 6, 29-58

[18]. Garcia, M, T. Osypuk, F. Werbel, A.I Meare, R. Coutler and B. Berkma (2004), "Housing Development and Human Degeneration". World Development, 28 (2)

[19]. Gbosh P Ked (1984), Third World Development: A Basic Need Approach Greenwood Press Connecticut

[20]. Gordon S (2008), Analyzing the Patterns of Government Expenditure in Canada. Canadian Public Administration: 101-120

[21]. Goulet, D (1971), "The Cruel choice: A New Concept in the Theory of Development" Atheum, New York

[22]. Grammy, A.S. and D. Assane (1996), Evidence of the Effect of Education Expenditure on Household Welfare. Applied Economic Letters, $4: 121-124$.

[23]. Gupta, S.B and M. Verhoeven (2001), The Efficiency of Government Expenditure: Evidence from Africa. Journnal of Policy Modeling, 23(4): 433-467

[24]. Hao, E and J. Fan (2001), “Design and Implementation of the Vietnam Human Development Programmes- the 'Poor' or the 'Shocked'?" World Bank Policy Research Working Paper No 2436, Washington, D.C

[25]. Haq M.U. (1995), Reflections on Human Development. Oxford University Press, New York.

[26]. Harun, M. B Rashid and B. M Azali (2003), "Public Expenditure Impact on Income Distribution in Malaysia". Singapore Economic Review Vol.34 (2): 33-46.

[27]. Herbison, R. and T. Hanushek (1997), "Determinants of Government Expenditure: Evidence from Disaggregated Data". Oxford Bulletin of Economics and Statistics, 57

[28]. Hezelland, R and F. Thorat (2005), The impact of Government Expenditure on Human Development: A Welfare Analysis for India. Journal of Policy Modeling, 13 (3).

[29]. Hicks N. (1980), "Economic Growth and Human Development" World Bank Working Paper No 408.

[30]. IMF (2006), "Nigeria, Options for Reforming Inter-governmental Fiscal Relations". Fiscal Affairs Department. February

[31]. International Monetary Fund (IMF) (2000), Global Economic Outlook. Washington, D.C

[32]. International Institute of Sustainable Development (2004), "Seeing the Light, Adopting Climatic changes with Decentralized renewable Energy in Developing Countries". http:/www.iisdu.org

[33]. Jaff, M.B (2003), "Energy Sector Privatization in Africa: Perspectives from Rural Electrification". http:/www.esi.africa.com

[34]. Jeff, M. (2007), "Breaking the Stranglehold on Growth. Why Policies Promoting Human Development offer a Better choice for the U.S. Economy”. EPI Briefing Paper, 192, Washington D.C.

[35]. Jung, H. S. and E. Thorbecke (2003), "The Impact of Public Expenditure on Human Development and Poverty Reduction in Tanzania and Zambia: A General equilibrium Approach". Journal of Policy Modeling Vol. 25 (8): 701-725

[36]. McGillivary M. (1991), "The Human Development Index: Yet another Redundant Composition Development Indicator". World Development, 19

[37]. McGillivary $M$ and $H$ White (1993), "Measuring Development? The UNDP's Human Development Index". Journal of International Development 5: 183-192

[38]. Mundle, S (1998), "Financing Human Development: some Lesson from Advanced Asian Countries". World Development, 26 (4): 659-672

[39]. Murray, H. (1993), “A Modified Human Development Index”, World Development, Vol. 26(3).

[40]. Musgrave, R. A and P.B Musgrave (1984), Public Finance in Theory and Practice, New York, McGraw-Hill. 
[41]. Musgrove Philip., Riadh Zeramdini and Guy Carrin (2000), "Basic Patterns in National Health Expenditure". Bulletin of the World Health Organization

[42]. Nasaruddin Arshad and Zulkifly Hj Mustapha (2000), "Malaysian Government Expenditure: An Analysis of Pattern and Probable Distribution Impact". Journal of Political Economy Analysis 3(1).

[43]. Noorbakhsh, R. (1998), “A Modified Human Development Index”. World Development, 26 (3): 51 -528

[44]. Odusola, A.F. (1997), Poverty Appraisal in Nigeria: An Eclectian Appraisal. In: Poverty Alleviation in Nigeria. Selected Papers, Annual Conference, NES.

[45]. Okojie, C.E.E. (1995), "Human Development for Productivity Growth in Nigeria”. Central Bank of Nigeria Economic and Financial Review 1(1) June 45.

[46]. Orubu, C.O. (2004), "Measuring the Quality of Life: Evolution and the Need to Adjust Disaggregated Country Indexes to Reflect Local Conditions". In: Abdul-Ganiyu Garba, et al (Eds). Leading Issues in Macro-Economic Management and Development: Ibadan, Nigerian Economic Society.

[47]. Pastmark, G (2006), Energy Sector Reform and the Pattern of the Poor: Energy use and supply of cross-country study. ESMAP Technical Paper 95, March

[48]. Ranis, G, F. Stewart and A Ramirez (2000), “Economic Growth and Human Development” World Development. Vol. 28 (2): 10021037.

[49]. Ranis, G. F and F. Stewart (2002), Strategies for Success in Human Development. Journal of Human Development Vol, 1 (7)

[50]. Ranjit, K.P, B. Dhritidyuti, B. Indranil and C. Jai (2006), Public Expenditure and Emerging Social Policy Scenario. Department of Economic Analysis and Policy. Reserve Bank of India

[51]. Ravallion, M (2001), Growth, Inequality and Poverty: Looking Beyond Averages. African Economic Research Consortium Plenary Paper, Nairobi, June

[52]. Ray, N.S and M.G Bhattacharaya (1992), An Appraisal of the Methodologies in Data Issues Relating to Human Development Analysis. In: G. K and G.V.S.N Murthy (eds). Human Development in India: Data Base Issues. New Delhi, Vikas Publishing House

[53]. Saghir, J (2005), Energy and Poverty: Myths, Links and Policy Issues. Energy Working Note 4

[54]. Sahn, D. E. and S.Younger (1999), Social Sector Expenditures and Human Development in Africa. Working Paper 99/172. Fiscal Affairs Department, International Monetary Fund.

[55]. Sen, A. K. (1981), Public Action and Quality of Life in Developing Countries. Oxford Bulletin of Economic and Statistics 43 (4): 287-319

[56]. Sen, A. K (1983), Development: Which Way Now? The Economic Journal 93, December.

[57]. Sen, A. K (1985), Well-Being, Agency and Freedom: The Dewey Lectures 1984, The Journal of Philosophy Vol. 82 (4): $169-221$

[58]. Sen, A. K (1999), Development as Freedom, Oxford, Oxford University Press

[59]. Sen, A. K (2000), A Decade of Human Development. Journal of Human Development. Vol.1 (1)

[60]. Seers, D (1989), The Meaning of Development. In: Eleventh World Conference of the Society for International Development. New Delhi

[61]. Strauss, J (1986), Does Better Nutrition Raise Farm Productivity? The Journal of Political Economy, Vol. 94 (2), 297-320

[62]. Strauss, J and D. Thomas (1998), Nutrition and Economic Development. Journal of Economic Literature, Vol. 36 (2), $766-817$

[63]. Streeten, P. (1994), From Growth to Basic Needs. Finance and Development. Vol. 16(3).

[64]. Streeten, P (1995), "Human Development - means and ends" American Economic Review, Vol. 8 (2), $232-237$.

[65]. The International Panel on Climate Change (IPCC, 2001)

[66]. Tilak, J.B.G (2002), "Elasticity of changes in Education expenditure on Household welfare in Rural India". South Asia Economic Journal, 3 (2)

[67]. Todaro, M.P. and S.C. Smith (2008), Economic Development ( $8^{\text {th }}$ Ed). England. Pearson Education

[68]. UHCHS (HABITAT) (2001), Housing in a Globalizing World, An Urbanizing World: Global Report on Human Settlements. London, Earthscan Publications

[69]. United Nations Centre for Human Settlement (2002), Strategies to Combact Homelessness. New York: Oxford University Press

[70]. UNDP (1990), Human Development Report, New York: Oxford University Press

[71]. UNDP (1994), Human Development Report, New York: Oxford University Press

[72]. UNDP(1996), Disaggregated Human Development index within Nigeria. Consultancy Report. UNDP, HDR Office, New York

[73]. UNDP (Various Issues), Human Development Report, New York: Oxford University Press

[74]. UNDP (2007), "Human Development Network- Measuring Country Performance in Health Selected Indicators for 115 Countries" Washington, D.C: The World Bank Human Development Report, New York.

[75]. UNDP (2009), Human Development Report Nigeria (Growth with Equity), Abuja: Soma Prints Limited

[76]. United Nations (1954), Report of International Definition of Standard and Level of Living. United Nations, New York.

[77]. UNDP (2006), "Energizing Human Development: A Review of Energy-Human Development Nexus". Human Development Strategy Paper.

[78]. United Nations Research Institute for Social Development (UNRISD) (1972), Content and Measurement of Socio Economic Development. Prager Publishers. New York.

[79]. Vaclcav, S. (2007), Energy and Sustainable Development. UNDP study on Energy, Working Paper

[80]. Wildlife Fund (2006), "Environmental Protection for the Millennium Development Goals". Achieving the Millennium Development Goals. Millennium Project

[81]. World Bank (1993), Federal Republic of Nigeria Social Sector Strategy Review. World Bank

[82]. World Bank (2000), Attacking Poverty. World Development Report. Washington: Oxford University Press

[83]. World Bank (2005), "Development in Practice: Private sector Development in Low- Income Countries". Washington, D C.: World Bank

[84]. World Bank (1993), “The Making of East Asian Miracle: World Bank Policy”. Research Bulletin (4), August- October.

[85]. World Bank (2006), Taking Action to Reduce Poverty in Sub-Saharan Africa. Washington, D.C. World Bank.

[86]. World Bank (1996), Trends in Developing Economics. Washington, D.C. World Bank.

[87]. World Bank (1996), Nigeria Poverty in the midst of Poverty: The Challenges of Growth with Inclusion. Washington DC, World 14733, May

[88]. World Bank (2003), "Nigeria Policy Option for Growth and Stability". Report No. 26215-NGA June.

[89]. World Bank (2004), World Development Report, Washington, D.C. World Bank

[90]. World Bank (2006), "Fiscal Policy for Growth and Development". A Draft Interim Report of the Development Committee, April.

[91]. Zuckman, S., J. Hadley and L. Lezzon (1994), Measuring Health Expenditure Efficiency with Frontier Cost Functions. Journal of Economics, 13 (3): 255-280 